\title{
The effect of shopping platform and product type on antecedents of online consumer behaviour - A proposed framework
}

\author{
Shekhar Singh, Assistant Professor ${ }^{1}$, \\ Dr. Sandeep Srivastava, Assistant Professor ${ }^{2}$ \\ ${ }^{I}$ Department of Humanities \& Social Sciences Jaypee University of Engineering and Technology, Guna, (M.P.) \\ India - 473226 \\ ${ }^{2}$ Department of Humanities \& Social Sciences Jaypee University of Engineering and Technology, Guna, (M.P.) \\ India - 473226
}

\begin{abstract}
From selling furniture to local grocery through e-commerce portals, Indian e-commerce market has come a long way (Radhakrishnan, 2016). As per Assocham-Deloitte joint study 2015, the global e-commerce industry is generating revenue of $\$ 2.4$ million every minute (Narasimhan, 2015). Every year, the investments made by foreign players in India keep increasing for the burgeoning e-commerce Indian market. Every new player, as their first step, is trying to understand the complex and vexing Indian consumer. In the last two decades, substantial amount of studies have been done in e-commerce sector to understand the online shopping behaviour of consumers. Mostly these studies have been conducted in foreign context, especially in United States, China, and some European and South-east Asian countries. In this paper, critical analysis of these studies has been done and discussed. Afterwards, few critical factors are identified and a theoretical model is proposed to understand the Indian online consumer.
\end{abstract}

Keywords: online consumer behaviour, mobile-commerce, electronic-commerce

\section{INTRODUCTION}

Two decades back, when Internet came to existence in India, nobody had envisioned its growth from few thousands to above 450 million internet users (Internelivestats.com, 2016). From portals like Rediff.com and Sify.com, Indian internet landscape has evolved a long way owing to success of homegrown players like Flipkart.com, Snapdeal.com etc. Now, we are moving to an era, where e-commerce has paved way to mcommerce and more e-commerce players are investing heavily on bringing innovative technology to the consumers (Criteo Research, 2016). Global e-commerce behemoths like Amazon, Alibaba, and Softbank etc. have already made big inroads into fast growing Indian market with their deep pockets, international experience and sector expertise (PWC Report, 2015). Owing to favorable demographics (young educated population), increasing Internet penetration, affordable technology (smartphones and internet connections) and rising standard of living, India pictures a lucrative and attractive market for these global players (PWC Report, 2015). But these opportunities don't come without its challenges.

Currently, the big players in the Indian market are majorly focusing on the discount based model. But providing steep discounts on every other product is not sustainable in long run and there lies the challenge (Srivas, 2016). For how long these big companies afford to give discounts riding on investors and venture capitalists money. Amazon.com took 13 years since its inception to turn profitable in United States (McFarlane, 2014) and that too in a market which isn't considered price sensitive like India. Now, in a country like India where majority of the customers are price sensitive and majority of sales numbers are only boosted through umpteen discount deals on various occasions and these promotions are only making the Indian consumers greedy, which per se questions the sustainability of such model in the coming years (Sharma, 2016). Hence, it becomes interesting area of research to identify factors which help in understanding the Indian consumers and unraveling of key determinants which might help these big players into developing a long term sustainable model.

Criteo Research, 2016 reveals that online shopping through mobile platform has become the preferable choice for customers in Asia Pacific region. It was found that 60 percent and 54 percent of all ecommerce transactions in Taiwan and Southeast Asia respectively are done through mobile shopping platform. As per Assocham report, 78 percent of the shopping queries in 2015 in India were made through mobile devices as compared to 46 percent in 2013 (Narasimhan, 2016). This clearly demonstrates that Indian online consumers are gradually shifting towards mobile devices and smartphones are the new game changer in this sector. Hence, it becomes naturally interesting area to explore the antecedent factors in context of m-commerce as well. 
Online consumer behaviour, online shopping experience, online purchase behaviour etc. has been widely researched area in last three decades (Zhou et al, 2007; Rose et al, 2011; Bourlakis et al, 2008). There has been number of articles and research papers published in variety of marketing, psychology and information technology journals. The scope of these studies have been broad and researchers have explored theories from psychology, information systems and marketing discipline and have applied and developed these theories to understand the behaviour of online consumers. Gamut of factors has been discussed in different researches and different underlying theories give different perspective for understanding the online consumer. Sometimes, the conclusions also differ because of different objectivity of these studies and different sectors in which these studies (ranging from shopping books, to banking, to purchasing medicaments etc.) have been conducted. Therefore, the main objectives of this study are threefold: i) to understand the main underlying theories which have been explored in literature related to this research area, ii) to identify common determinant factors which are found relevant in past studies and critically examine these factors in light of Indian online consumers and iii) to propose a comprehensive theoretical research framework for comparative study of significant driving factors of m-commerce and e-commerce.

This paper is organized in following fashion: a) in section 2, brief summary of the literature survey conducted for this study is discussed, b) in section 3, major theories adopted in various research studies are discussed, c) in section 4, key determinant factors identified from various studies are discussed, d) in section 5, factors identified in the previous section are examined in view of Indian online consumers e) in section 6, online shopping behaviour typology and theoretical model is proposed, and f) finally, conclusion and discussion regarding future directions for research is carried out.

\section{LITERATURE REVIEW}

The literature survey for the study was conducted by going through over 200 research papers collected from various electronic databases like EBSCO, ProQuest etc. In the survey, latest research papers included were until June 2016 and covered past relevant literature went back as old as 1999.

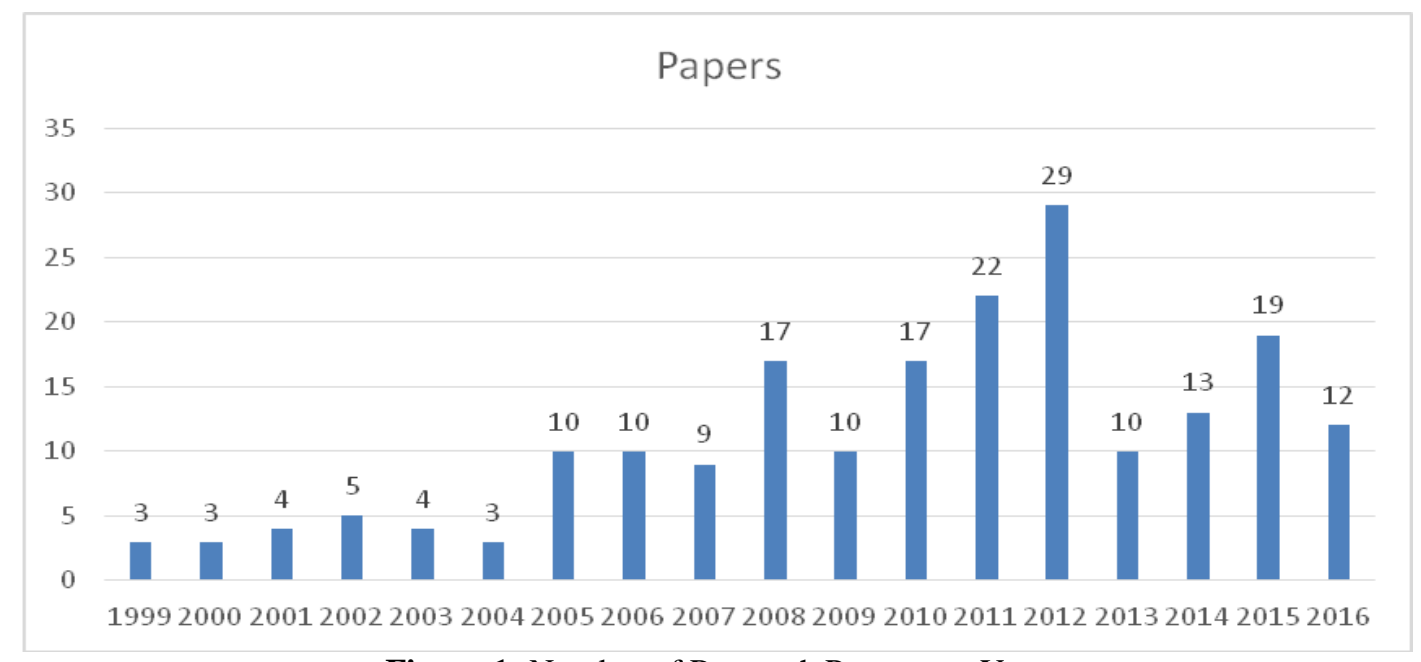

Figure 1: Number of Research Papers per Year

Out of these 180 research papers, 77 research papers have been analyzed and arranged in chronological order for identifying major underlying theories and determinant factors for further analysis and discussion. In the literature analysis, attempt has been made to include only those papers which are relevant to our research objective and exhaustive in nature.

\section{Major Theories}

\section{Theory of Reasoned Action (TRA)}

The Theory of Reasoned Action (TRA) was developed by Icek Ajzen and Martin Fishbein. The theory deals with explaining the voluntary behavior of human actions arising due to already existing attitudes and behavioral intentions (Ajzen \& Fishbein, 1975). As explained below in Figure 2, behaviour is shown as outcome of behavioural intention which per se is result of attitude towards the act or behaviour and subjective norm influencing the individual (Ajzen \& Fishbein, 1980). 


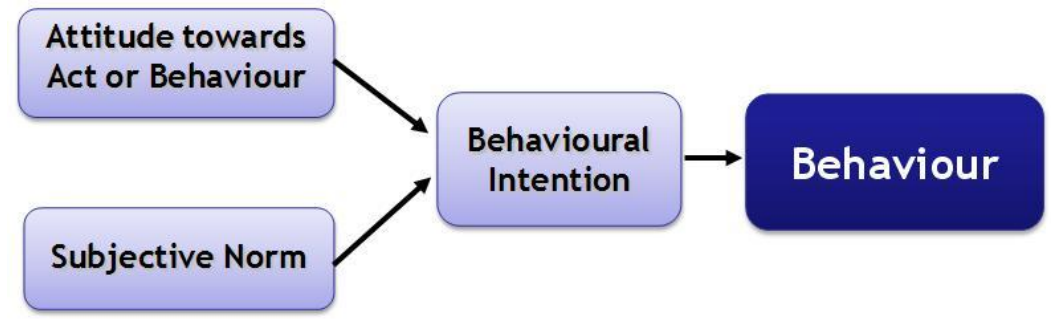

Figure 2: Theory of Reasoned Action

For example, if a person voluntarily smokes, according to this theory - this action is basically an outcome of the attitude (beliefs, value systems and dispositions) that the person has developed over years through his surroundings, upbringings, and approval of the social group (family, friends, peers) in which he lives in.

\section{Theory of Planned Behaviour (TPB)}

The Theory of Planned Behaviour was the extension of authors' previous work (Theory of Reasoned Action) by Ajzen and Fishbein (Ajzen, 1991). In their earlier work, behavior was considered to be voluntary by Ajzen and Fishbein, but later it was realized that behaviour can't be always completely voluntary and within control (Ajzen, 1985). Hence, in this theory, behavior is defined as planned and deliberate and a third component is included called perceived behavioral control to predict planned human behaviour. Like the previous model, behaviour is still an outcome of attitude \& subjective norm, but a new determinant is added, i.e. Perceived behavioral control which basically explains the individual's self-perception of the control he possesses for a particular behaviour. Therefore, perceived behavioral intention influences both the intention and behaviour and thus, it becomes the ultimate factor which guides the individual's actual behavioral control as explained below in Figure 3 (Ajzen, 1991).

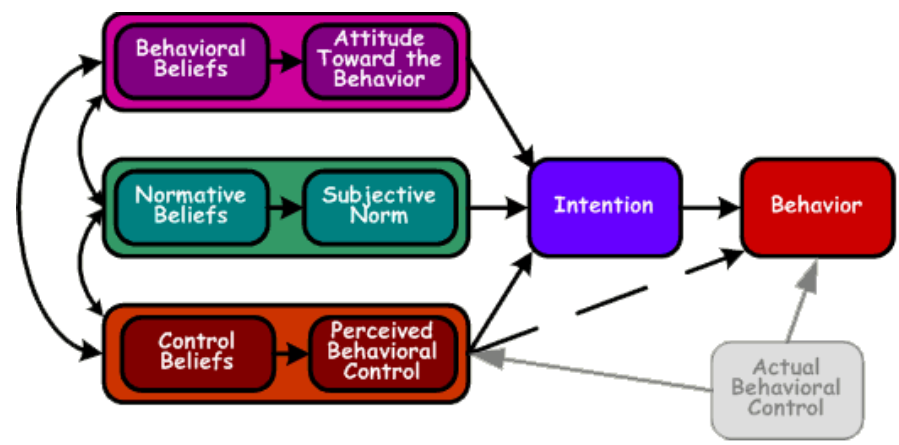

Figure 3: Theory of Planned Behaviour

For example, suppose a person intention may be negative towards smoking due to the attitude (owing to behavioral beliefs) and subjective norm (owing to normative beliefs), but his perceived belief is that he doesn't have control/power to stop smoking and this will ultimately control his actually behaviour of planned smoking.

\section{Technology Acceptance Model (TAM)}

The Technology Acceptance Model was developed by Davis in 1989 in his published doctoral thesis. The model attempts to explain how individuals learn to accept and are ready to adopt new technology. The major factors responsible for any successful technology acceptance as defined in this model are Perceived usefulness and Perceived ease of use (Davis, 1989). Majorly, the model has been generally applied for studying acceptance for information systems and computer technology in real life.

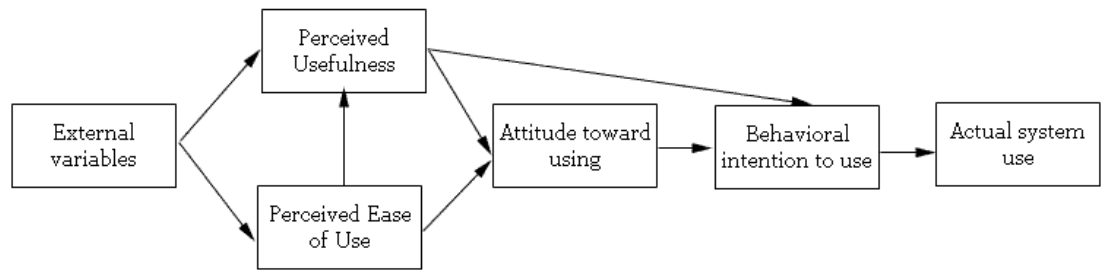

Figure 4: Technology Acceptance Model 
As shown above in Figure 4, perceived usefulness and perceived ease of use will influence the attitude and behaviour towards the computer usage. Davis defined perceived usefulness as any person's perception towards the fact that how the use of new technology can improve and enhance his life (Davis, 1989). Perceived ease of use was defined as any user's perception regarding the ease with which the user can learn and operate the new technology. In the model, Davis also assumed that these two factors are dependent on external variables like social factors, demographics factors, cultural factors etc. which necessarily influences the perceived beliefs of individuals. In recent years, TAM has been explored and extended into different model versions, i.e. TAM2, TAM3 etc. with addition of new factors by various researchers (Venkatesh \& Davis, 2000; Venkatesh \& Bala, 2008).

\section{Expectation Confirmation Model - IT (ECM-IT)}

Expectation confirmation theory in marketing was proposed by Richard Oliver. Originally, the theory was developed to explain the post-purchase and post-adoption satisfaction of users as a function of expectations, perceived performance and disconfirmation of beliefs (Oliver, 1977). Later, this theory was adopted and explored in Information System (IS) field to explain the post-purchase satisfaction related to use of information technology and information system (Oliver, 1980). Bhattacherjee in his work in 2001, explained the continuance of IS usage through factors of confirmation and perceived usefulness (Bhattacherjee, 2001).

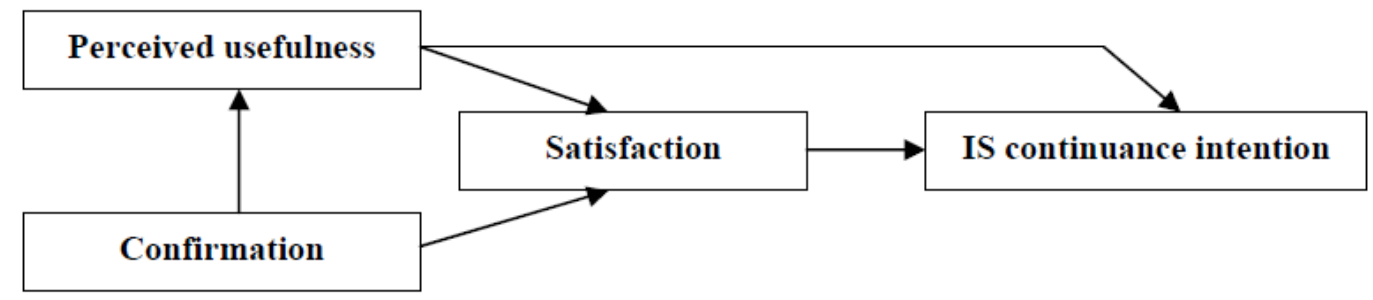

Figure 5: Expectation Confirmation Model

As explained above in Figure5, Bhattacherjee posited that with initial technology usage, every user has some expectations beforehand and if these expectations are substantiated post usage, it leads to positive perceived usefulness and as a result of both these factors, a feeling of satisfaction is evoked in the user which ultimately leads to continued use of the new IS/IT.

\section{Determinant factors of online consumer behaviour Attitude}

Attitude is outcome of the behavioural beliefs and feelings which an individual possesses regarding any particular action (Ajzen, 1991). It can be positive and negative and ultimately, it influences the degree of intention to perform behaviour. Many researchers have shown that attitude towards online shopping is a significant determinant of making online purchases (Yang et al.,2007) and purchasing behavior (George, 2004; Yang et al., 2007).

\section{Subjective norm}

Subjective norm is function of all the perceived pressure an individual faces in view of family, friends, peers and society (Ajzen, 1991). If an individual feels that a particular behaviour will be appreciated or approved by people around him, he will have more intention to perform that particular behaviour. The literature suggests a positive relationship between subjective norm and intended behavior, and empirical work has shown that subjective norm influences behavioral intentions toward system use (Karahanna et al. 1999).

\section{Perceived behavioral control}

Ajzen (1991) added perceived behavioral control as third antecedent for predicting actual planned behaviour. It is defined as individual's perception of his capability and control to perform behaviour. It is outcome of past experiences and anticipated hurdles while performing a behavior which influences both the intention to perform the behaviour and the actual behavior. Previous studies have found that the Planned Behavioral Control (PBC) directly influences online shopping behavior (George, 2004).

\section{Intention}

Ajzen (1991) defined intention as purposive measurement of any individual's willingness to carry out a particular behavior. As mentioned in the theory of reasoned action, it is described as function of both - attitude towards a behavior and subjective norms towards that behavior. Online purchase intention can also be characterized as a circumstance where a buyer is ready and expects to make online exchanges (Pavlov, 2003).

DOI: 10.9790/0837-2206037383 www.iosrjournals.org $\quad 76 \mid$ Page


There are many instances in recent studies where significant relationship was found between purchase intention and purchase behaviour (Venkatesh et. al, 2003; George 2002; Venkatesh, 2000; Ajzen, 1991; Ajzen, 1985).

\section{Perceived usefulness}

In Technology acceptance model, perceived usefulness is described as the user's belief in terms of likelihood that using a specific application / information system will improve his or her life (Davis 1989). Many researchers have found perceived usefulness as an important predictor of a consumer's intention to shop from a particular online retailer (Lee, Fiore and Kim, 2006).

\section{Perceived ease of use}

In Technology acceptance model, perceived ease of use is described as the extent to which the user anticipates the application system to be independent of any effort (Davis 1989). In context of online shopping, it can be also defined as the degree to which a consumer expects to buying products online would be effortless (Taylor and Todd 1995b). Web site's perceived ease of use has a direct influence on trust, which per se affects consumers' intended use of the website (Gefen and Straub 2000).

\section{Perceived risk}

Perceived risk is defined as the possible loss perceived by a shopper while comparing a product purchase through online channel vis-à-vis offline channel (Amaro, 2015).Hence, the amount and nature of risk perceived by consumer in purchases made on online medium is referred as perceived risk (Cox and Rich, 1964).Any possible negative outcome related to uncertain nature of electron transaction as perceived by online consumers is perceived risk (Kim et. al., 2007). Tan, 1999 concluded that higher perceived risk may lead consumer to offline purchases whereas low perceived risk increase the likelihood of online shopping. In online context, two types of risks are of paramount nature: privacy risk \& security risk (Chen and Barnes, 2007). Perceived security risk is the danger generally associated with the computer safety, security of credit card or any financial information shared over the online medium (Bart et. al, 2005). Perceived privacy risk is the danger generally associated with privacy of shared personal information over the online medium and the ability to control the collection and usage of information by the web vendors (Castaneda \& Montoro, 2007).

\section{Trust}

When one party has feelings of confidence and security towards the other party, it leads to creation of sense of trust (Rempel, Holmes, and Zanna, 1985). Hence, when a person has confidence and faith in the other person, then only the first person will have trust in the transaction (Moorman, Zaltman and Deshpande, 1992). Trust is considered as important antecedent factor in online transactions and lack of it leads consumers to be less willing to go for the e-commerce transaction (Lee and Turban, 2001; Chen and Barnes, 2007; Gefen, 2000). It is also defined as confident belief that the first party will not exploit the second party's vulnerabilities even if circumstances are there (Hosmer, 1995; Moorman et al., 1992).

\section{Hedonic motivation}

In psychology, hedonic motivation is characterized by effect of pleasure or pain receptors which leads a person to move towards an action or move away from it (Higgins, 2006). When a shopper looks for attaining amusement, entertainment, fun, relaxation, enjoyment, excitement from any shopping activity, this motivation is referred as hedonic motivation (Hirschman, 1980; Hausman 2000; Sahney et al, 2008). Many researchers have found out that hedonic motivation encourages shopping activities of consumers in both online and offline channels (Baumgartner, 2002; Zhou, Dai, and Zhang 2007).

\section{Utilitarian motivation}

When a shopper is goal \& task oriented, rational and takes shopping as a problem solving activity, such shopper is defined as utilitarian shopper (Wolfinbarger and Gilly, 2001). Such consumers have certain objective while shopping and they treat this activity efficiently and accomplish it in timely manner (Monsuwe et al., 2004). Many studies have concluded that utilitarian shoppers has willingness and intention to shop online due to factors like ease of use, usefulness, convenience, broad product spectrum, minimum physical effort, accessibility (Liu \& Forsythe, 2010; Dennis et al., 2010; Kim and Foresythe, 2009).

Demographics - Demographic variables are among the most frequently studied factors by the researchers. The effect of age, gender, income group, education and culture on behaviour of consumer while shopping has been researched a lot in past (Bellman et al. 1999; Li et al. 1999; Swaminathan et al. 1999). Most of research questionnaires for studying online consumer behaviour have questions related to demographics (Fram \& Grandy, 1995). Innovativeness, income, and household size were directly linked to consumer's willingness for 
adopting internet as shopping platform (Sultan \& Henrichs, 2000). Age, education, gender, marital status, residential location and income were commonly observed as imperative indicators for online shopping (Fram \& Grady, 1997; Kunz, 1997; Sultan \& Henrichs, 2000).

\section{Website characteristics}

Kim et al., (2003) mentioned in their study that quality reflects through websites based on three parameters: presentation quality, adequate functions and content, and navigational capabilities. They also commented that reliability and response rate of the websites characterized the performance of any website. For creating first impression and attracting consumers, website design, captivating appearance, simple layout, effective navigation, and up-to-date information are the primary requisites (Wakefield et al., 2004). For creating trust in consumer's mind, a web vendor is required to produce a high quality website to demonstrate its sincere interest for its customers (Cheung et al., 2005).

\section{Internet Self-efficacy}

Bandura (1986) defined self-efficacy as individual judgments of a person's capabilities to accomplish a particular behavior. Internet self-efficacy is defined a person's self judgment of his or her internet skills whether it is sufficient enough to apply on any internet related activity like shopping (Eastin and LaRose, 2000).Many researchers have found out that shoppers with high internet self efficacy are more comfortable with online shopping (Eastin and LaRose, 2000). For undertaking any behavioral action, possessing necessary skills and knowledge is an important requisite (Koufaris 2002). Therefore, the self-efficacy factor is considered as important factor for studying online shopping behavior (Eastin, 2002).

\section{Perceived Usability}

Casalo et. al (2007) defined the expected effort required to use a computer system as perceived usability. Nielson (1994) referred that usability is linked to various aspects of a system such as the ease of managing the system, learning its basic functions, degree of efficiency of the system and error free handling of the system by the user. In online context, many researchers have extended the term perceived usability to perceived website usability (Flavia'n et al., 2006). Many researchers have considered this as an important factor influencing the shopping behaviour of the consumer (Kim \& Eom, 2002; Liang \& Lai, 2002; Mandel \& Johnson, 1999).

\section{Relevant antecedent factors in Indian context}

Khare and Rakesh (2011) conducted a survey on a sample of 325 students to determine the antecedents of online shopping behaviour in Indian context. The results of the study showed that Indian student's intention to purchase online is impacted by utilitarian value, attitude towards online shopping, availability of information, and hedonic values. In the study, male students were found to have more positive attitude towards online shopping as compared to female students. In another study, impulse purchase orientation, prior online purchase experience and online trust were found to have significant impact on the customer purchase intention (Thamizhvanan and Xavier, 2012). The results also concluded that males have more intention to shop online than females. Hence, online retailers were recommended to target the impulse purchase orientation nature of Indian consumers and to focus on increasing online trust.

Thakur and Srivastava (2012) conducted an empirical study on customer usage intention of mobile commerce in India. The purpose of the study was to investigate the factors impacting the adoption intention of mobile commerce. Perceived usefulness, perceived ease of use and social influence were found to be significant dimensions of technology adoption readiness to use mobile commerce. The results also indicated perceived credibility risk defined by security risk and privacy risk to be significantly negatively related to behavioural intention demonstrating that these concerns are important in deterring customers from using mobile commerce.

Gehrt et al. (2012) explored the Indian online shopping orientations based on sample of 538 consumer panel members. Three shopping orientation segments were identified: value singularity, quality at any price, and reputation/recreation. The quality at any price and reputation/recreation segments were found to be the predominant online shoppers. Although their orientations toward shopping differed, their behaviour, web site attribute ratings, and demographics were very similar except for occupation (managerial versus clerical, respectively). Consumer self-efficacy and website social-presence were found to affect trust, perceived usefulness and perceived risk for the online customers, which in turn positively influence the customer's intention to purchase products online (Das and Saji, 2008).Similarly, perceived risk, fear related to delivery of products were found to highest concern for Indian consumers and information quality, product range, visual design and after online sales service were the most preferred website attributes (Mishra \& Mathew, 2013). However, Dahiya (2012) stated on-line shopping in India is significantly affected by various demographic factors like age, gender, marital status, family size and income. 


\section{PROPOSED THEORETICAL RESEARCH MODEL}

In context of the review of the extant literature thus far, it becomes imperative to draw upon the picture that emerges. Based on the extant literature reviewed in the above sections, a conceptual model is proposed to examine the online shopping behaviors of Indian consumers (Figure 6). The model is primarily rooted in the theory of planned behaviour and includes some commonly acknowledged factors in literature. This model examines (i) the relationship between attitude, subjective norms, perceived usability, perceived risk, perceived self-efficacy, trust and purchase intention towards online shopping behaviour and (ii) the model also intends to explore the moderating impact of shopping platform on the relationship between factors of the model when run for different product type.

In light of the above perspective, it is all the more important that a holistic view of online shopping behavior be understood. To that end - as also discussed in the introduction section - it is noteworthy that nowadays mobile commerce is gaining a lot of significance in the overall e-commerce sector across the world. Therefore, it becomes mandatory to understand the online shopping behavior of Indian consumers in both the contexts i.e. mobile platform vs. traditional platform (laptop, desktop). Hence, in this study it is proposed that the conceptual research model should be studied as per the typology demonstrated in Figure 7.

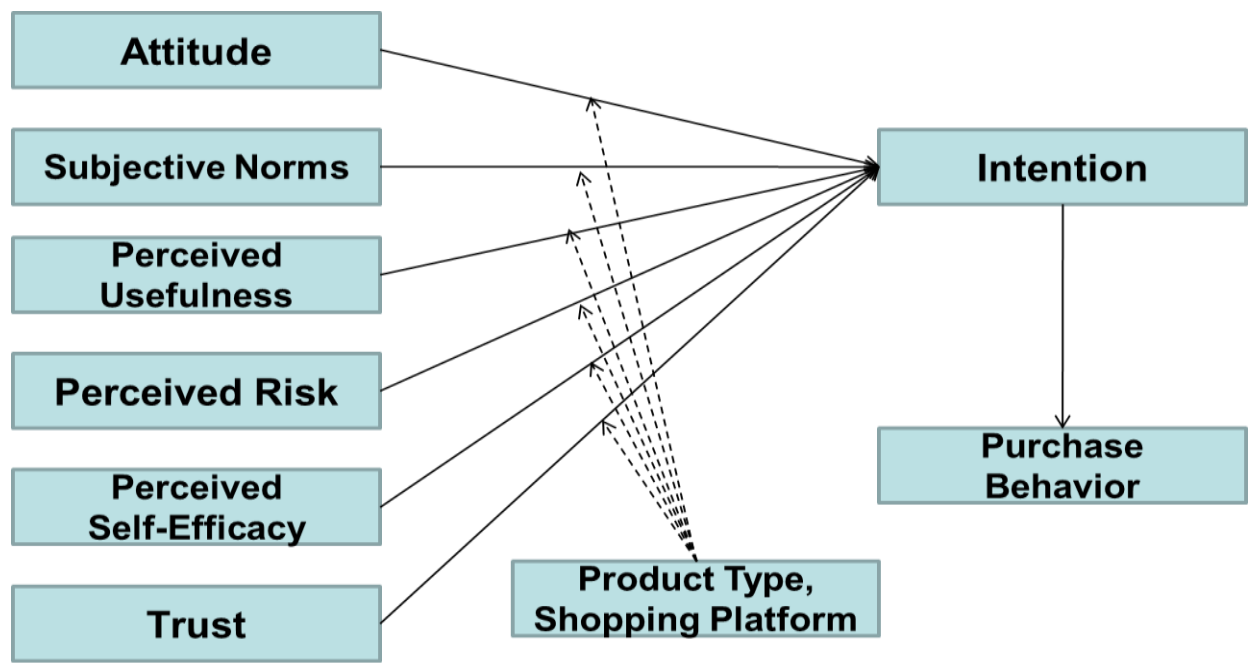

Figure 6: Proposed Research Model

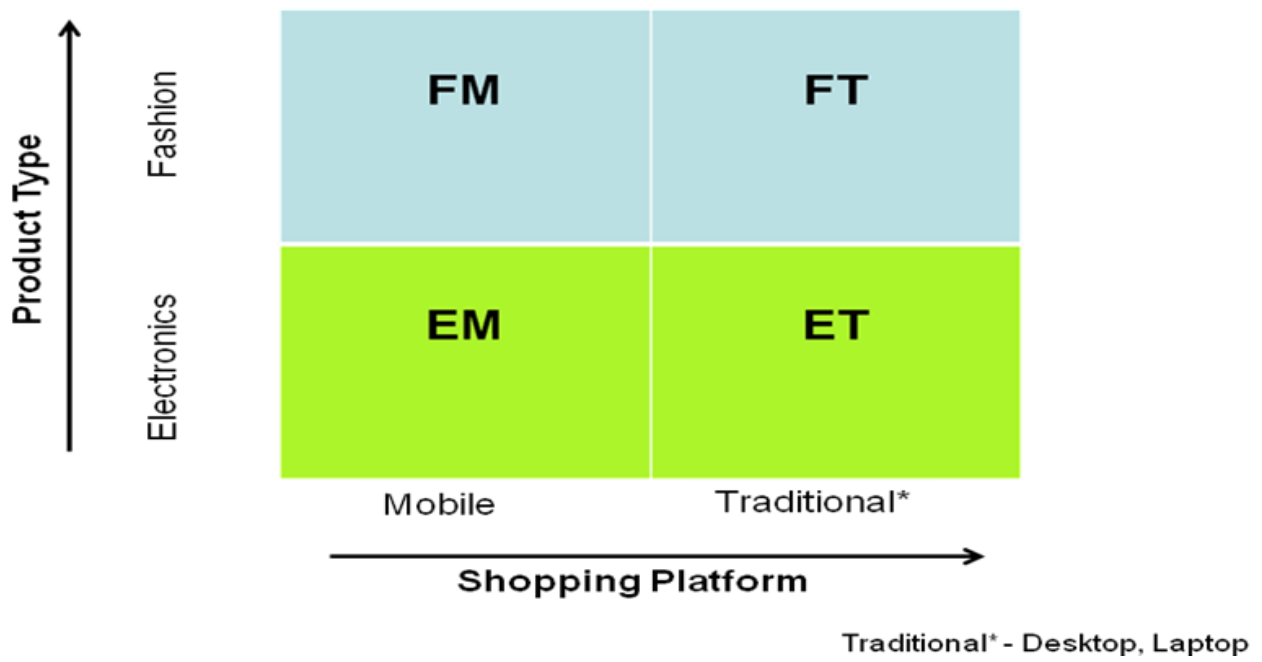

Figure 7: Proposed Theoretical Framework

In figure 7, a $2 \times 2$ matrix is developed showing four quadrants representing four different combinations between product type and type of shopping platform. Each quadrant represents a research area focusing on tracing the consumer's online shopping behaviour in a particular scenario. For the study, the two product categories recommended are fashion (apparels \& accessories) and electronics as these two categories account for the bulk of India's retail e-commerce sales (ASSOCHAM-PwC study, 2016). 


\section{CONCLUSION \& FUTURE DIRECTIONS}

All in all, this paper primarily focuses on the exhaustive study of relevant extant literature and thereafter proposes a research framework which can be further explored and empirically tested in future studies. Several key determinant factors from past literature have been identified from the vast literature review and these factors along with the popular theories of theory of planned behaviour and technology acceptance model underpin the conceptual research model proposed in this paper. Amongst other insights that the paper seek to provide, a striking feature of the paper is the recommendation of exploring two popular product categories from Indian online shopping electronic space: fashion and electronics. Subsequently other product categories can also be empirically tested on the model and valuable insights can be drawn from such study. The model like other conceptual model may have some limitations as all the factors can't be included in the model at the same time which makes the empirical analysis complex and leading interpretation of results to become confusing and conflicting.

\section{REFERENCES}

[1]. Ajzen, I. (1985). From intentions to actions: a theory of planned behavior. In Kuhl, J., Beckmann, J.(Eds), Action Control: From Cognition to Behavior, Springer-Verlag, New York, NY, 11-39.

[2]. Ajzen, I. (1991). The Theory of Planned Behavior. Organizational Behavior and Human Decision Processes, Vol. 50, Iss. 2, 179-212

[3]. Amaro, S., \& Duarte, P. (2015). An integrative model of consumers' intentions to purchase travel online. Tourism Management, 46, 64-79.

[4]. Arpita Khare \& Sapna Rakesh (2011). Antecedents of Online Shopping Behavior in India: An Examination. Journal of Internet Commerce, 10:227-244.

[5]. Arun Thamizhvanan \& M.J. Xavier (2013). Determinants of customers' online purchase intention: an empirical study in India. Journal of Indian Business Research, Vol. 5 No. 1, 17-32

[6]. ASSOCHAM PwC study, (2016). Online shopping defying slowdown; set to rise 78\% this year [Online] Available at: http://www.assocham.org/newsdetail.php?id=5581 [Accessed 8 August 2016]

[7]. Bandura, A. (1994). Self-efficacy: The Exercise of Control. W.H. Freeman, New York, NY

[8]. Baumgartner, H. (2002). Toward a personology of the consumer. Journal of Consumer Research 29 (2), 286-292.

[9]. Bellman, S., Lohse, G. L. \& Johnson, E. J. (1999). Predictors of Online Buying Behavior. Communications of the ACM, Vol. 42, No. 12 32-38.

[10]. Bhattacherjee A. (2001). Understanding information systems continuance - An expectation confirmation model. MIS Quarterly, Vol. 25, No.3, 351-370.

[11]. Bourlakis M., Papagiannidis S. \& Fox Helen, (2008). E-Consumer Behaviour: Past, Present and Future Trajectories of an Evolving Retail Revolution. International Journal of E-Business Research, 4(3), 64-76.

[12]. Chen, Y., \& Barnes, S. (2007). Initial trust and online buyer behavior. Industrial Management \& Data Svstems, 107(1), 21-36.

[13]. Cheung, C. M. K., Chan, G. W. W., \& Moez, L. (2005). A critical review of online consumer behavior: Empirical research. Journal of Electronic Commerce in Organizations, 3(4), 1-19.

[14]. Cox, D. F., \& Rich, S. J. (1964). Perceived Risk and Consumer Decision - Making: The case of Telephone Shopping. Journal of Marketing Research, 1(4), 32-39.

[15]. Criteo Research, (2016). [Online]. Available from http://www.criteo.com/media/5333/criteomobilecommercereport-h12016-us.pdf [Accessed 17 November 2016]

[16]. Dahiya Richa (2012). Impact of demographic factors of consumers on online shopping behaviour: a study of consumers in India, I.J.E.M.S., VOL.3 (1), 43-52.

[17]. Davis, F. D. (1989). Perceived usefulness, perceived ease of use, and user acceptance of information technology. MIS Quarterly, 13 (3), 319-340.

[18]. Dennis, C., Morgan, A., Wright, L.T., \& Jayawardhena, C. (2010). The influences of social e-shopping in enhancing young women's online shopping behavior. Journal of Customer Behaviour, 9(2), 151-174.

[19]. E. Kim \& S. Eom (2002). Designing effective cyber store user interface. Industrial Management and Data Systems, 102(5), 241-251.

[20]. Eastin, M. S. (2002). Diffusion of e-commerce: An analysis of the adoption of four e-commerce activities. Telematics and Informatics, 19, 251-267.

[21]. Eastin, M.S. and LaRose, R. (2000). Internet self-efficacy and the psychology of the digital divide. Journal of Computer-Mediated Communication, Vol. 6 No. 1.

[22]. Fiore, A., Kim, J., \& Lee, H. (2005). Effect of image interactivity technology on consumer responses toward the online retailer. Journal of Interactive Marketing, 19(3), 38-53.

[23]. Fram, E. H., \& Grandy, D.B. (1995). Internet buyers: Will the surfers become buyers? Direct Marketing, Vol. 57, No. 10, 63-65. 
[24]. Fram, E. H., \& Grandy, D.B. (1997). Internet shoppers: Is there a surfer gender gap? Direct Marketing, Vol. 59, No. 1, 46-50.

[25]. Gefen, D. (2000). E-commerce: The role of familiarity and trust. International Journal of Management Science, 28, 725-737.

[26]. Gefen, David and Straub, Detmar W. (2000). The Relative Importance of Perceived Ease of Use in IS Adoption: A Study of E-Commerce Adoption. Journal of the Association for Information Systems: Vol. 1: Iss. 1, Article 8.

[27]. Gehrt et. al (2012), Emergence of online shopping in India: shopping orientation segments, International Journal of Retail \& Distribution Management, Vol. 40 No. 10, 742-758.

[28]. George, J. F (2002). Influences on the intent to make internet purchases. Internet Research: Electronic Networking Applications and Policy, vol.12, 2, 165-180.

[29]. George, J. F. (2004). The theory of planned behavior and Internet purchasing. Journal of Internet Research, 14(3), 198-212.

[30]. Hausman, A. 2000. A multi-method investigation of consumer motivations in impulse buying behavior. Journal of Consumer Marketing 17 (5), 403-419.

[31]. Higgins, T.E. (2006). Value from hedonic experience and engagement. American Psychological Association. vol 113, no. 3, 439-460.

[32]. Hirschman, E. C. (1980). Innovativeness, novelty seeking and consumer creativity. Journal of Consumer Research, 7, 283-295.

[33]. Hosmer, L. T. (1995). Trust: the connecting link between organizational theory and philosophical ethics. Academy of Management Review, 20(2), 379-403.

[34]. Internet Live Stats (2016). [Online]. Available from http://www.internetlivestats.com/internet-users/india/ [Accessed 15 November 2016].

[35]. J.A. Castañeda \& F.J. Montoro (2007). The effect of Internet general privacy concern on customer behavior. Electronic Commerce Research, vol 7, 117-41.

Bart, Y., Shankar, V., Sultan, F., \& Urban, G. L. (2005). Are the drivers and role of online trust same for all websites and consumers? A large-scale exploratory empirical study. Journal of Marketing, 69, 133152.

[36]. Karahanna, E., Straub, D. W., and Chervany, N. L. (1999). Information Technology Adoption across Time: A Cross-Sectional Comparison of Pre-Adoption and Post-Adoption Beliefs. MIS Quarterly (23:2), 183-213.

[37]. Kim, D. J., Ferrin, D. L., \& Rao, H. R. (2007). A trust-based consumer decision-making model in electronic commerce: The role of trust, perceived risk, and their antecedents. Decision Support System, 44, 544-564.

[38]. Kim, J., \& Forsythe, S. (2009). Factors affecting adoption of product virtualization technology for online consumer electronics shopping. International Journal of Retail \& Distribution Management, 38(3), 190204.

[39]. Kim, S.E., Shaw, T. and Schneider, H. (2003). Web site design benchmarking within industry groups. Internet Research: Electronic Networking Applications and Policy, 13(1), 1726.

[40]. Kunz, M.B. (1997). On-line customers: identifying store, product and consumer attributes which influences shopping on the Internet. Published doctoral dissertation. The University of Tennessee, Knoxville.

[41]. L. Casalo' et al. (2008). The role of perceived usability, reputation, satisfaction and consumer familiarity on the website loyalty formation process. Computers in Human Behavior (24), 325-345.

[42]. Lee, M. K. O., \& Turban, E. (2001). A trust model for consumer internet shopping. International Journal of Electronic Commerce, 4(1), 75-91.

[43]. Li, H., Kuo, C. and Russell, M. G. (1999). The Impact of Perceived Channel Utilities, Shopping Orientations, and Demographics on the Consumer's Online Buying Behavior. Journal of ComputerMediated Communication, Vol. 5, No. 2.

[44]. Liu, C, \& Forsythe, S. (2010). Sustaining Online Shopping: Moderating Role of Online Shopping Motives. Journal of Internet Commerce, 9, 83-103.

[45]. M. Fishbein and I. Ajzen (1975). Belief, Attitude, Intention and Behavior: An Introduction to Theory and Research. Addison-Wesley.

[46]. M. Fishbein and I. Ajzen (1980). Understanding attitudes and predicting social behavior. Englewood Cliffs, NJ: Prentice-Hall.

[47]. McFarlane, Greg (2014). Amazon Never Makes Money But No One Cares [Online] Available at: http://www.investopedia.com/stock-analysis/031414/amazon-never-makes-money-no-one-cares-amznaapl-wag-azo.aspx [Accessed 12 March 2016] 
[48]. Moorman, C., Zaltman, G., \& Deshpande, R. (1992). Relationship between providers and users of marketing research: the dynamics of trust within and between organizations. Journal of Marketing Research, 29(3), 314-329.

[49]. N. Mandel \& E. Johnson (1999). Constructing preferences online: can web pages change what you want? Working Paper, WhartonSchool, University of Pennsylvania.

[50]. Narasimhan, P. (2015). E-commerce industry makes $\$ 1.2 \mathrm{~m}$ revenue in every 30 seconds. [Online]. Available at: http://www.thehindu.com/business/Industry/ecommerce-generates-12mn-revenue-every-30seconds-study/article7557638.ece. [Accessed: 07 October 2015].

[51]. Narasimhan, P. (2016). E-commerce industry to cross $\$ 38$ billion this year: Assocham [Online]. Available at: http://www.thehindu.com/business/E-commerce-industry-to-cross-38-billion-this-yearAssocham/article13977121.ece. [Accessed: 07 April 2016].

[52]. Oliver, R. L. (1977). Effect of Expectation and Disconfirmation on Post exposure Product Evaluations an Alternative Interpretation. Journal of Applied Psychology, 62(4), 480.

[53]. Oliver, R. L. (1980). A Cognitive Model of the Antecedents and Consequences of Satisfaction Decisions. Journal of Marketing Research, 17(4), 460.

[54]. Pavlou, P. A. (2003). Consumer acceptance of electronic commerce: Integrating trust and risk with the technology acceptance model. International Journal of Electronic Commerce, 7(3), 197-226.

[55]. PWC Report, 2015. [Online]. Available from http://www.pwc.in/assets/pdfs/publications/2015/ecommerce-in-india-accelerating-growth.pdf [Accessed 20 June 2016].

[56]. Radhakrishnan, K (2016). Why grocery is next big thing in e-commerce. [Online] Available at: http://www.dnaindia.com/money/report-why-grocery-is-next-big-thing-in-e-commerce-2222133 [Accessed 7 July 2016].

[57]. Rakhi Thakur \& Mala Srivastava (2013). Customer usage intention of mobile commerce in India: an empirical study, Journal of Indian Business Research, Vol. 5, No. 1, 52-72.

[58]. Rempel, J. K., Holmes, J. G., \& Zanna, M. P. (1985). Trust in close relationships. Journal of Personality and Social Psychology, 49(1), 95-112.

[59]. Rose Susan, Neil Hair, Moira Clark (2011). Online Customer Experience: A Review of the Business-toConsumer Online Purchase Context, International Journal of Management Reviews, Vol. 13, 24-39.

[60]. Sahney, S., Shrivastava, A., \& Bhimalingam, R. (2008). Consumer Attitude towards Online Retail Shopping in the Indian Context. The lCFAI University Journal of Consumer Behavior, 3(4).

[61]. Satyabhusan Dash \& K. B. Saji (2008). The Role of Consumer Self-Efficacy and Website SocialPresence in Customers' Adoption of B2C Online Shopping: An Empirical Study in the Indian Context, Journal of International Consumer Marketing, Vol. 20(2), 33-48.

[62]. Sharma, Itika (2016). For Indian e-commerce, the choice is between discount and bleed or profit and die. [Online] Available at: http://qz.com/754119/indian-e-commerce-companies-will-die-without-discounts/ [Accessed 18 October 2016].

[63]. Sita Mishra \& Priya M Mathew (2013). Analyzing Perceived Risks and Website attributes in E-Retailing: A Study from India, Journal of Internet Banking and Commerce, vol. 18, no.2.

[64]. Srivas, Anuj (2016). Time to Bid Farewell to the Great E-Commerce Discount? [Online] Available at: http://thewire.in/26653/time-to-bid-farewell-to-the-great-e-commerce-discount/ [Accessed 4 April 2016].

[65]. Sultan, F., \& Henrichs, R.B. (2000). Consumer preferences for Internet services overtime: initial explorations. The Journal of Consumer Marketing, Vol. 17, No. 5, 386-403.

[66]. Swaminathan, V., Lepkowska-White, E. and Rao, B. P. (1999). Browsers or Buyers in Cyberspace? An Investigation ofFactors Influencing Electronic Exchange. Journal of Computer-Mediated Communication, Vol. 5, No. 2.

[67]. T. Liang \& H. Lai (2002), Effect of store design on consumer purchases: an empirical study of online bookstores, Information and Management (39), 431-444.

[68]. Tan, S. J. (1999). Strategies for reducing consumer's risk aversion in Internet shopping. Journal of Consumer Marketing, 16(2), 163-178.

[69]. Taylor, S., \& Todd P. A. (1995). Understanding Information Technology Usage: A Test of Competing Models. Information SystemsResearch (6:3), 144-176.

[70]. Venkatesh, V. (2000). Determinants of perceived ease of use: integrating control, motivation and emotion.

[71]. Venkatesh, V., Morris, M.G., Davis, G.B. and Davis, F.D. (2003). User acceptance of information technology: toward a unified view. MIS Quarterly, Vol. 27 No. 2, 425-78.

[72]. Venkatesh, V. \& Bala, H. (2008). Technology Acceptance Model 3 and a Research Agenda on Interventions. Decision Sciences, 39 (2), 273-315. 
[73]. Venkatesh, V. \& Davis, F. D. (2000). A theoretical extension of the technology acceptance model: Four longitudinal field studies. Management Science, 46 (2), 186-204.

[74]. Wakefield, R. J., Stocks, M. H., \& Wilder, W. M. (2004). The role of Web site characteristics in initial trust formation. Journal of Computer Information Systems, 45(1), 94-103.

[75]. Yang, B., Lester, D., \& James, S. (2007). Attitudes toward buying online as predictors of shopping online for British and American respondents. Cyber Psychology and Behavior, 10(2), 198-203.

[76]. Zhou, L., L. Dai, \& D. Zhang. (2007). Online shopping acceptance model: A critical survey of consumer factors in online shopping. Journal of Electronic Commerce Research 8 (1), 41-62. 